\title{
Determinants of Business Performance in the Nigerian Manufacturing Sector
}

\author{
Nwakoby, Nkiru Peace ${ }^{1}$ Ph.D, Dibua, Emmanuel Chijioke ${ }^{2}$ PhD, Ezeanolue Uju Scholastica ${ }^{3}$ \\ 1Department of Entrepreneurship studies, Nnamdi Azikiwe University (NAU), Awka, Nigeria \\ 2Department of Business Administration, Nnamdi Azikiwe University (NAU), Awka, Nigeria \\ 32Department of Business Administration, Anambra State Polytechnic, Mgbakwu, Nigeria
}

\begin{abstract}
How to cite this paper: Nwakoby, Nkiru Peace Ph.D | Dibua, Emmanuel Chijioke $\mathrm{PhD} \mid$ Ezeanolue Uju Scholastica "Determinants of Business Performance in the Nigerian Manufacturing Sector" Published in International Journal of Trend in Scientific Research and Development

(ijtsrd), ISSN: 2456-

6470, Volume-3 |

Issue-3 , April 2019,

pp.760-766, URL:

https://www.ijtsrd.c

om/papers/ijtsrd23

141.pdf

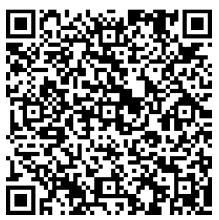

Copyright (c) 2019 by author(s) and International Journal of Trend in Scientific Research and Development Journal. This is an Open Access article distributed under the terms of the Creative Commons

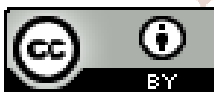

Attribution License (CC BY 4.0) (http://creativecommons.org/licenses/ by $/ 4.0$ )

\section{INTRODUCTION}

Most of the businesses in Africa and Nigeria in particular, fall within the Small and Medium Enterprises (SMEs). This business type is a key indicator of the overall performance of most economy in Africa and it is responsible for most of the employment opportunities realized and Jobs created (Mohammed, 2017). A research survey showed that SMEs constitute about 97 percent of all businesses in Nigeria and generate about 50 percent of employment. They also produce 30 percent of manufacturing output (National Policy on Micro, Small and Medium Enterprises, NPMSMES, 2006; Debbie (2004). The 2010 National MSMEs Collaborative Survey puts the number of Micro, Small and Medium Enterprises (MSMEs) in Nigeria at 17,284,671 with a total employment of 32,414,884 and contributing 46.54 percent to the GDP in nominal terms (Ebitu, Basil \& Ufot, 2016). This study focuses on the manufacturing subsector of the industrial sector. Thirteen manufacturing and allied activities make up the manufacturing sector. It comprised of Oil Refining, Cement, Food, Beverages and Tobacco; Textile, Apparel, and Footwear; Wood and Wood products; Pulp Paper and Paper products; Chemical and Pharmaceutical products; Non-metallic Products, Plastic and Rubber products, Electrical and Electronic, Basic Metal and Iron and Steel; Motor Vehicles and Assembly; and Other Manufacturing (NBS,2014). The manufacturing sector of successful economies is perceived as a critical sector in terms of share of total output and employment. Growth in this sector according to (Anigbogu, Edoko and Okoli, 2016) has long been considered crucial for sustainable economic growth and development. The manufacturing sector is a subsector of the industrial sector. When a nation is industrialized, there is a deliberate and sustained application and combination of an appropriate technology, infrastructure, managerial expertise and other important resources. Suffix it therefore to state that iindustrialization is the core driver of the modern economy. It acts as a catalyst for ensuring and accelerating the pace of structural transformation and diversification of economic resources. It enables a country to fully utilize its factor endowment and to depend less on foreign supply of finished goods or raw materials for its economic growth, development and sustainability (Oburota \& Ifere, 2017). Consequently, the 
manufacturing sector which is a subsector of the industrial sector is therefore a critical in the process of industrialization.

This special interest in manufacturing stems from the belief that the sector is a potential engine of modernization, a creator of skilled jobs, and a generator of positive spill-over effects. The growth in manufacturing output has been a key element in the successful transformation of most economies, mostly the developed and emerging economies that have seen sustained rises in their per capita incomes (Tybout, 2000). Thus, in wake of the ailing performance of this sector, most African governments have made remarkable strides in revamping the sector. Precisely, Nigeria has taken various major steps to foster the private sector role in the country's economic and social development. The government has acted to reorient economic policy, stimulate nonoil Small and Medium Enterprise (SME) development, promote foreign investment, reform the financial architecture, and put in mechanism in place to combat corruption and strengthen the institutional framework, among others. However, all these are laudable effort on the part of the government. But instigating polices to rejuvenate this sector involves not just policy formulation, however, in-depth examination on the factors (like financial intermediation, infrastructure, market size, Exchange rate, interest rate etc) that influence the sector performance is imperative for policy implications. Thus, evaluating the impact of these government-oriented structural policies on business performances depends explicitly on how they affect business performances in Nigeria. This study investigates the major determinants of business performance with a special focus on the manufacturing sector in Nigeria via some selected determinants of industry performance.

\section{Statement of the Problem}

This study was informed by the dismal performance of Nigeria's manufacturing sector orchestrated by the high level of graduate unemployment, poverty, corruption and other types of social vices which constitute a threat to the nascent democracy and further investments in Nigeria, thereby perpetuating underdevelopment. Sangosanya (2011) posited that the growth, performance and productivity of Nigeria's manufacturing firms have deteriorated at present and even beyond the rate at which they grew in the past three decades when manufacturing still played significant roles in the Nigerian economy. National Bureau of Statistics (2018) and other economic analysts reports that over 4million jobs were lost between 2015 and 2018 and many multinational companies like Michelin, Dunlop etc closed down and relocated to other countries as a result of perceived unfavourable economic climate. The Manufacturers Association of Nigeria (MAN) also declared that over 820 manufacturing companies have closed down in the past one decade between 2000 and 2015 of civilian rule and rendered thousands of people jobless, even as the Federal Government said the solution may not be very quick in coming (Obembe, Adebisi \& Adesina, 2011). In the business policy literature, Hansen and Birger (1989) developed a theoretical hypothesis using two major streams of research on the determinants of firms' performance: economic and organization factors. The economic factor is based primarily upon an economic tradition, emphasizing the importance of external market factors in determining firm success. The other line of research builds on the behavioral and sociological paradigm and sees organization factors and their fit with the environment as the major determinants of success. These two major streams of research dominated literature on firm performance thus creating a literature and by extension a knowledge gap in this part of the world where environment and policy factors arguably influences firm performance in Nigeria. This study therefore investigates some selected determinants of industry performance like financial intermediation, infrastructure, market size, Exchange rate and interest rate to ascertain their influence on the performance of manufacturing firms in Nigeria.

\section{Objectives of the Study}

The main objective of the study is to ascertain the major determinants of business performance in the Nigeria's manufacturing sector. Specifically, the study intends to determine the influence of financial intermediation, infrastructure, market size, Exchange rate and interest rate on the performance of manufacturing firms in Nigeria.

\section{RELATED EMPIRICAL LITERATURE}

Okunade (2018) examined the effect of Capacity Utilisation on Manufacturing Firms' Production in Nigeria using time series data covering the period of 1981 to 2016 through an Autoregressive Distributed Lag (ARDL) model approach. The study found positive but insignificant relationship between capacity utilisation and manufacturing firms' output since capacity was grossly under utilised in virtually every productive firm in Nigeria. Adebayo and Onyeiwu (2018) examined the determinants of profitability of manufacturing firms in Nigeria using a panel data regression analysis via the fixed effect, random effect and Hausman test were conducted to analyze the data and the outcome was that all the explanatory variables were important determinants of profitability in the Nigerian manufacturing sector though it emphasized that efficient utilization of assets is more significant than the asset size. Ududechinyere, Eze and Nweke (2018) investigated the influence of manufacturing sector output on economic growth in Nigeria from 1981 to2016using Autoregressive Distributed Lag (ARDL) model and Granger causality technique. The results showed that manufacturing capacity utilization (MCU) has positive influence on RGDP while manufacturing output (LMO) affects RGDP positively. It also showed that government investment expenditure (GINVEXP) has negative effect on RGDP whereas money supply (LM2) influenced RGDP positively. More so, evidence of unidirectional causality is established between RGDP and MCU, LMO and LM2. Akinyele, Akinyele and Ajagunna (2016) examined infrastructural development as predictor to small and medium enterprises performance In Nigeria. Their main objective was to critically examine the effects of certain infrastructures on the performance of small and medium scale enterprises and to achieve this, salient issues on main infrastructures such as education, power/electricity, technology and transportation were examined to analyse what effects they have on SMEs using some performance measures such as; business survival, profitability, sales turnover and product/service delivery. ANOVA was used in testing these hypotheses of the study. Findings showed that there is a significant positive correlation between infrastructures and SME performance which implies that infrastructures play a huge role in ensuring the successful business operation of SMEs. Adeyemi and Olufemi (2016) investigated the determinants of capacity utilization in the Nigerian manufacturing sector between 1975 and 2008 using capacity utilization as the dependent variable while its 
determinants such as Real Manufacturing Output Growth Rate (MGDP), Real Interest Rate (INTR), Consumer's Price Index (CPI), Fixed Capital Formation in Manufacturing Sector (CPF) and Electricity Generation on Rate(ELEGR)(Proxy for energy) were used as independent variables. Co integration and Error Correction Model(ECM) were employed as the estimation techniques so as to study the time series properties of the variables and to ascertain the existence of long-run relationship between capacity utilization and its determinant indicators. Structured questionnaire was administered to assess the operational materials and the performance of the selected firms. The findings of the study revealed that there is positive relationship between consumer's price index, Fixed capital formation in manufacturing sector and capacity utilization. The study also showed that there is negative relationship between Electricity Generation, Real Manufacturing Output Growth Rate and Capacity Utilization which resulted in low manufacturing productivity growth rate in Nigeria. Ajudua and Ojima (2016) analyzed the determinants of output in the Nigerian manufacturing sector from 1986 - 2014. Gross Capital Formation, Bank Credit to Manufacturing Sector, Lending Rate, Employed labour Force, Foreign Direct Investment, Manufacturing Capacity Utilisation Rate, and Foreign Exchange Rate were used as explanatory variables and were regressed on manufacturing sector output (dependent variable). The Unit root test using the Augmented Dickey Fuller test was conducted to test for stationarity among variables. The Johansen Co-integration test was also employed to test for long run equilibrium relationship among the variables; the Granger Causality test was conducted so as to ascertain the causal relationship between variables while the stability test was also conducted to check for the long run stability of the variables employed. The paper found a significant relationship between the explanatory variables employed and the output of the manufacturing sector in Nigeria during the period studied. Otalu and Keji (2015) carried out an assessment of the determinants of industrial sector growth in Nigeria using co integration and error correction model. Result shows that all the identified determinants have more of permanent effect on industrial output than transitory effect. Both labour and capital have significant impact, exchange rate shows a positive and significant impact indicating that currency appreciation might be inimical to the growth of the industrial sector. Mojekwu and Iwuji (2012) examined the impact of some macroeconomic variables and power supply on the performance of the Nigerian manufacturing sector using least square multiple regression technique. The main findings of the study were that power supply had positive and significant impact on capacity utilization while inflation rate and interest rate had negative impact on capacity utilization. However, the impact of interest rate was significant at $5 \%$ level while lending rate was insignificant. The regression model explained $88.54 \%$ of the variation in capacity utilization, after correcting for linearity, normality, auto-correlation and heteroscedascity. Olorunfemi, Tomola, Felix, and Ogunleye (2013) examined manufacturing performance for sustainable economic development in Nigeria using a Panel data analysis on secondary data from 1980-2008 that was extracted from CBN Statistical Bulletin. The results indicate positive relationship between manufacturing and each of capacity utilization and import. There is a negative relationship between manufacturing and each of investment, exchange rate, and export. The study showed that investment, capacity utilization and import were major determinants of manufacturing performance for the period. Loto (2012) investigated the determinants of output expansion in the Nigerian manufacturing industries between 1980-2010 using regression models of the Ordinary Least Square. One of the important findings of the preceding analysis is that inflation rate plays the highest significant role in explaining manufacturing output expansion between 1980 -2010. Real GDP and per capita real GDP have positive and significant roles to play in the manufacturing output expansion. There is inverse relationship between output expansion and capacity utilization in manufacturing. Gathenya, Bwisa and Kihoro (2011) examined interaction between Women Entrepreneurs' Age and Education on Business Dynamics in Small and Medium Enterprises in Kenya. An exploratory cross-sectional survey was carried out. The sample comprised of 128 small and medium scale women entrepreneurs. The results of the interaction of the UNIANOVA analysis revealed that there was significant interaction between the effects of both age and education on locus of planning. Both also had a significant impact on the profitability of the enterprises when firm performance was measured as return on asset. Simon-Oke, and Awoyemi (2010) investigated the impact of manufacturing capacity utilization on industrial development in Nigeria during the period of 1976 - 2005. Manufacturing capacity utilization, value added and employment generation were regressed on index of industrial productivity (which served as the proxy for industrial development) using the co-integration and error correction mechanism as analytical tools. Findings revealed that there is a long run positive relationship between Manufacturing capacity utilization, value added and index of industrial productivity in Nigeria.

From the available literature, it is observed that the performance of the Nigerian manufacturing sector is volatile and ailing, thus, in wake of the ailing performance of this sector, the government has made remarkable strides in revamping the sector. Precisely, Nigeria has taken various major steps to foster the private sector role in the country's economic and social development. The government has acted to reorient economic policy, stimulate nonoil Small and Medium Enterprise (SME) development, promote foreign investment, reform the financial architecture, and put in mechanism in place to combat corruption and strengthen the institutional framework, among others. However, all these are laudable effort on the part of the government. But instigating polices to rejuvenate this sector involves not just policy formulation, however, in-depth examination on the factors (determinants) that influence the sector performance. Thus, evaluating the impact of these government-oriented structural policies on business performances depends explicitly on how they affect the determinants of business performances in Nigeria. As earlier stated, two major streams of research on the determinants of firms' performance: economic and organization factors dominate literature on firm performance in Nigeria which have created a literature and by extension a knowledge gap in this part of the world where environment and policy factors arguably influences firm performance in Nigeria. This study therefore investigates some selected determinants of industry performance like financial intermediation, infrastructure, market size, Exchange rate and interest rate to ascertain their influence on the performance of manufacturing firms in Nigeria. 


\section{METHODOLOGY}

\section{Model Specification}

The model for this study is developed in such a way that it incorporates the variables perceived as missing gap in the literature reviewed and this study deem fit to be the determinants of business performance on Nigerian manufacturing sector. The study employed manufacturing sector as the dependent variable while financial intermediation, infrastructure, market size, exchange rate, interest rate and inflation as the determinants of business performance and they serve as the explanatory variables in this study. Thus, the model for the study is as follows:

The functional form of the model is:

MAFS $=\mathrm{f}($ FIN, INFRA, MATZ, EXCH, INTR, INFL)

(1)

The mathematical form of the model is:

MAFS $=\beta_{0}+\beta_{1}$ FIN $+\beta_{2}$ INFRA $+\beta_{3}$ MATZ $+\beta_{4}$ EXCH $+\beta_{5}$ INTR $+\beta_{6}$ INFL (2)

The econometric form of the model is:

MAFS $=\beta_{0}+\beta_{1}$ FIN $+\beta_{2}$ INFRA $+\beta_{3} \mathrm{MATZ}+\beta_{4} \mathrm{EXCH}+\beta_{5}$ INTR

$+\beta_{6}$ INFL $+\alpha_{i}$

Where: MAFS = Manufacturing sector proxied by manufacturing output

FIN= Financial intermediation

INFRA = Infrastructure

MATZ = Market size

$\mathrm{EXCH}=$ Exchange rate

INTR $=$ Interest rate

INFL = Inflation rate

$\beta_{\mathbf{0}}=$ intercept

$\beta_{1}$ to $\beta_{6}=$ partial slope coefficients

Evaluation Technique and Procedure

The economic technique employed in the study is the ordinary least square (OLS). This is because the OLS computational procedure is fairly simple a best linear estimator among all unbiased estimation, efficient and shown to have the smallest (minimum variance) thus, it become the best linear unbiased estimator (BLUE) in the classical linear regression (CLR) model. Basic assumptions of the OLS are related to the forms of the relationship among the distribution of the random variance $\left(\mu_{\mathrm{i}}\right)$. OLS is a very popular method and in fact, one of the most powerful methods of regression analysis. It is used exclusively to estimate the unknown parameters of a linear regression model.

\section{DATA PRESENTATION AND DATA ANALYSIS}

The study attempted to explain the determinants of business performance in the Nigerian manufacturing sector from 1980 -2018 using Ordinary least Square (OLS) technique method. All data used are secondary data obtained from the Statistical Bulletin of Central Bank of Nigeria (CBN). In executing the study, the OLS techniques was applied after determining stationarity of our variables using the ADF Statistic, as well as the co integration of variables using the Johansen approach and was discovered that the variables are stationary and have a short term relationship among the variables in the model. The data are analyzed by OLS using $\mathrm{E}$ view. The summary of this and other preliminary tests discussed in chapter three are presented in the tables below.

\section{Summary of Stationary Unit Root Test}

Establishing stationarity is essential because if there is no stationarity, the processing of the data may produce biased result. The consequences are unreliable interpretation and conclusions. We test for stationarity using Augmented Dickey-Fuller (ADF) tests on the data. The ADF tests are done on level series, first and second order differenced series. The decision rule is to reject stationarity if ADF statistics is less than $5 \%$ critical value, otherwise, accept stationarity when ADF statistics is greater than $5 \%$ criteria value. The result of regression is shown in table 4.1 below.

Table 1: Summary of ADF test results

\begin{tabular}{|c|c|c|c|c|c|c|}
\hline Variables & $\begin{array}{c}\text { ADF } \\
\text { Statistics }\end{array}$ & $\begin{array}{c}\text { Lagged } \\
\text { Difference }\end{array}$ & $\begin{array}{c}1 \% \text { Critical } \\
\text { Value }\end{array}$ & $\begin{array}{c}\mathbf{5} \% \text { Critical } \\
\text { Value }\end{array}$ & $\begin{array}{c}\mathbf{1 0} \% \text { Critical } \\
\text { Value }\end{array}$ & $\begin{array}{c}\text { Order of } \\
\text { Integration }\end{array}$ \\
\hline MAFS & -5.303511 & 1 & -3.661661 & -2.960411 & -2.619160 & $I(1)$ \\
\hline FIN & -5.763376 & 1 & -3.661661 & -2.960411 & -2.619160 & $I(1)$ \\
\hline INFRA & -4.864043 & 1 & -3.653730 & -2.957110 & -2.617434 & $I(1)$ \\
\hline MATZ & -9.253889 & 1 & -3.653730 & -2.957110 & -2.617434 & $I(1)$ \\
\hline EXCH & -5.229408 & 1 & -3.653730 & -2.957110 & -2.617434 & $I(1)$ \\
\hline INTR & -6.728109 & 1 & -3.653730 & -2.957110 & -2.617434 & $I(1)$ \\
\hline INFL & -5.813439 & 1 & -3.661661 & -2.960411 & -2.619160 & $I(1)$ \\
\hline
\end{tabular}

Source: Researchers computation

Evidence from unit root table above shows that none of the variables are stationary at level difference that is, $I(0)$, rather all the variables are stationary at first difference, that is, $I(1)$. Since the decision rule is to reject stationarity if ADF statistics is less than $5 \%$ critical value, and accept stationarity when ADF statistics is greater than $5 \%$ criteria value, the ADF absolute value of each of these variables is greater than the $5 \%$ critical value at their first difference but less than $5 \%$ critical value in their level form. Therefore, they are all stationary at their first difference integration.

\section{Summary of Cointegration Test}

Cointegration means that there is a correlationship among the variables. Cointegration test is done on the residual of the model. Since the unit root test shows that none of the variable is stationary at level $I(0)$ but stationary at first difference 1(1), we go further to carry out the cointegration test. The essence is to show that although all the variables are stationary, whether the variables have a long term relationship or equilibrium among them. That is, the variables are cointegrated and will not produce a spurious regression. The result is summarized in the tables 2 below for Trace and Maximum Eigenvalue cointegration rank test respectively. 
International Journal of Trend in Scientific Research and Development (IJTSRD) @ www.ijtsrd.com eISSN: 2456-6470

Table 2: Summary of Johansen Cointegration Test

Unrestricted Cointegration Rank Test (Trace)

\begin{tabular}{|c|c|c|c|c|}
\hline Hypothesized No. of CE(s) & Eigenvalue & Trace Statistic & 0.05 Critical Value & Prob. $^{* *}$ \\
\hline None $*$ & 0.747371 & 161.0029 & 125.6154 & 0.0001 \\
\hline At most $1^{*}$ & 0.692505 & 116.9762 & 95.75366 & 0.0008 \\
\hline At most $2^{*}$ & 0.617249 & 79.23880 & 69.81889 & 0.0073 \\
\hline At most $3 *$ & 0.538991 & 48.50695 & 47.85613 & 0.0434 \\
\hline At most 4 & 0.327585 & 23.72815 & 29.79707 & 0.2121 \\
\hline At most 5 & 0.255467 & 11.02800 & 15.49471 & 0.2098 \\
\hline At most 6 & 0.048415 & 1.588050 & 3.841466 & 0.2076 \\
\hline \multicolumn{5}{|c|}{ Trace test indicates 4 cointegrating eqn(s) at the 0.05 level } \\
\hline \multicolumn{5}{|c|}{$*$ denotes rejection of the hypothesis at the 0.05 level } \\
\hline
\end{tabular}

\begin{tabular}{|c|c|c|c|c|}
\hline \multicolumn{5}{|c|}{ Unrestricted Cointegration Rank Test (Maximum Eigenvalue) } \\
\hline Hypothesized No. of CE(s) & Eigen value & Max-Eigen Statistic & 0.05 Critical Value & Prob.** \\
\hline None & 0.747371 & 44.02667 & 46.23142 & 0.0847 \\
\hline At most 1 & 0.692505 & 37.73744 & 40.07757 & 0.0897 \\
\hline At most 2 & 0.617249 & 30.73185 & 33.87687 & 0.1134 \\
\hline At most 3 & 0.538991 & 24.77880 & 27.58434 & 0.1097 \\
\hline At most 4 & 0.327585 & 12.70015 & 21.13162 & 0.4802 \\
\hline At most 5 & 0.255467 & 9.439954 & 14.26460 & 0.2514 \\
\hline At most 6 & 0.048415 & 1.588050 & 3.841466 & 0.2076 \\
\hline \multicolumn{5}{|c|}{ Max-eigenvalue test indicates no cointegration at the 0.05 level } \\
\hline \multicolumn{5}{|c|}{ Source: Researchers computation } \\
\hline \multicolumn{5}{|c|}{ rejection of the hypothesis at the 0.05 level } \\
\hline
\end{tabular}

Table 2 indicates that trace have only 4 cointegrating variables in the model while Maximum Eigenvalue indicated no cointegrating variables. Hence, the trace statistics and Eigen value statistics reveal that there is a short run relationship between the variables. That is, the linear combination of these variables cancels out the stochastic trend in the series. This will prevent the generation of spurious regression results. Hence, the implication of this result is a short run relationship between manufacturing sector and the determinants of business performance used in the model.

\section{Presentation of Result}

Having verified the existence of long-run relationships among the variables in our model, we therefore, subject the model to ordinary least square (OLS) to generate the coefficients of the parameters of our regression model. The result of the regression test is shown in table 3 below.

Table 3: Summary of regression results

\begin{tabular}{|c|c|c|c|c|}
\hline \multicolumn{5}{|c|}{$\begin{array}{l}\text { Dependent Variable: MAFS } \\
\text { Method: Least Squares } \\
\text { Sample: } 19802018 \\
\text { Included observations: } 39\end{array}$} \\
\hline Variable & Coefficient & Std. Error & t-Statistic & Prob. \\
\hline $\mathrm{C}$ & 351.8411 & 8.684687 & 2.405128 & 0.0886 \\
\hline FIN & 37.12074 & 1.855689 & 2.800375 & 0.0556 \\
\hline INFRA & 15.72785 & 1.018575 & 1.544103 & 0.1342 \\
\hline MATZ & 20.40608 & 7.042954 & 5.289737 & 0.0012 \\
\hline EXCH & -7.339559 & 5.124903 & -4.143214 & 0.0072 \\
\hline INTR & -12.98196 & 1.819291 & -3.456123 & 0.0519 \\
\hline INFL & -15.52669 & 4.809257 & -0.322850 & 0.7493 \\
\hline R-squared & 0.778177 & \multicolumn{2}{|c|}{ F-statistic } & 15.78641 \\
\hline Adjusted R-squared & 0.728883 & \multicolumn{2}{|c|}{ Prob(F-statistic) } & 0.000000 \\
\hline S.E. of regression & 4167.587 & \multicolumn{2}{|c|}{ Durbin-Watson stat } & 2.004310 \\
\hline
\end{tabular}

\section{Evaluation of Estimates}

To discuss the regression results as presented in table 3. We employ economic a priori criteria, statistical criteria and econometric criteria.

\section{Evaluation based on economic a priori criteria}

This subsection is concerned with evaluating the regression results based on a priori (i.e., theoretical) expectations. The sign and magnitude of each variable coefficient is evaluated against theoretical expectations. 
From table 3 , it is observed that the regression line have a positive intercept as presented by the constant (c) $=351.8411$. This means that if all the variables are held constant or fixed (zero), MAFS will be valued at 351.8411. Thus, the a-priori expectation is that the intercept could be positive or negative, so it conforms to the theoretical expectation.

It is observed in table 3 that financial intermediation, infrastructure and market size have a positive impact on manufacturing sector while exchange rate, interest rate and inflation rate have a negative impact on manufacturing sector in Nigeria, although, exchange rate was expected to be either positive or negative. This implies that a unit increase in financial intermediation, infrastructure and market size, will lead to an increase in the manufacturing sector productivity in Nigeria. On the other hand, increases in exchange rate, interest rate and inflation rate will lead to a decrease in the manufacturing sector productivity in Nigeria.

From table 3, it is observed that all the variables conform to the a priori expectation of the study. Thus, table 4 summarises the a priori test.

Table 4.4: Summary of economic a priori test

\begin{tabular}{|c|c|c|c|c|c|}
\hline \multirow{2}{*}{ Parameters } & \multicolumn{2}{|c|}{ Variables } & Expected Relationships & Observed Relationships & Conclusion \\
\cline { 2 - 5 } & Regressand & Regressor & & + & Conform \\
\hline$\beta_{0}$ & & Intercept & $+/-$ & + & Conform \\
\hline$\beta_{1}$ & & FIN & + & + & Conform \\
\hline$\beta_{2}$ & & INFRA & + & + & Conform \\
\hline$\beta_{3}$ & & MATZ & + & + & Conform \\
\hline$\beta_{4}$ & & EXCH & $+/-$ & - & Conform \\
\hline$\beta_{5}$ & & INTR & - & - & Conform \\
\hline$\beta_{6}$ & & INFL & - & & + \\
\hline
\end{tabular}

Source: Researchers compilation

Evaluation based on statistical criteria

This subsection applies the $\mathrm{R}^{2}$, adjusted $\mathrm{R}^{2}$, the S.E and the $\mathrm{f}-$ test to determine the statistical reliability of the estimated parameters. These tests are performed as follows:

From our regression result, the coefficient of determination $\left(\mathbf{R}^{2}\right)$ is given as 0.778177 , which shows that the explanatory power of the variables is very high and/or strong. This implies that $78 \%$ of the variations in the growth of the manufacturing sector are being accounted for or explained by the variations in financial intermediation, infrastructure, market size, exchange rate, interest rate and inflation rate in Nigeria. While other determinants of business performance not captured in the model explain just $22 \%$ of the variation in manufacturing sector in Nigeria.

The adjusted $\mathbf{R}^{2}$ supports the claim of the $\mathrm{R}^{2}$ with a value of 0.728883 indicating that $73 \%$ of the total variation in the dependent variable (manufacturing sector is explained by the independent variables (the regressors)). Thus, this supports the statement that the explanatory power of the variables is very high and strong.

The standard errors as presented in table 3 show that all the explanatory variables were all low. The low values of the standard errors in the result show that some level of confidence can be placed on the estimates.

The F-statistic: The F-test is applied to check the overall significance of the model. The F-statistic is instrumental in verifying the overall significance of an estimated model.

\section{Summary of Findings}

1. From the result of the OLS, it is observed that financial intermediation, infrastructure and market size have a positive impact on manufacturing sector while exchange rate, interest rate and inflation rate have a negative impact on manufacturing sector in Nigeria, although, exchange rate was expected to be either positive or negative. This implies that a unit increase in financial intermediation, infrastructure and market size, will lead to an increase in the manufacturing sector productivity in Nigeria. On the other hand, increases in exchange rate, interest rate and inflation rate will lead to a decrease in the manufacturing sector productivity in Nigeria.

2. From the regression analysis, the result show that all the variables conform to the a priori expectation of the study which indicates that financial intermediation, infrastructure, market size, exchange rate, interest rate and inflation rate are good determinants of business performance in the Nigerian manufacturing sector.

3. The F-test conducted in the study shows that the model has a goodness of fit and is statistically different from zero. In other words, there is a significant impact between the dependent and independent variables in the model.

4. The findings of the study also show that financial intermediation, market size, exchange rate and interest rate are statistically significant while infrastructure and inflation rate are statistically insignificant in explaining the growth of Nigerian manufacturing sector.

5. Finally, the study shows that there is a short run relationship exists among the variables. Both $\mathrm{R}^{2}$ and adjusted $\mathrm{R}^{2}$ show that the explanatory power of the variables is very high and/or strong. The standard errors show that all the explanatory variables were all low. The low values of the standard errors in the result show that some level of confidence can be placed on the estimates.

\section{Recommendations}

Based on the findings of this work, the following recommendations are made:

1. The energy sector needs to be overhauled especially the EEDC to supply just the sufficient energy to drive the economy. Every economy needs energy to grow and this is a major determinant of business performance. Thus, the federal government should embark on an allinclusive search for energy (with special attention paid 
on renewable sources) to augment the present energy mix in the country.

2. Painstaking and well-coordinated macro-economic policies with special references to the price level and exchange rate regime need to be put in place to ameliorate the business sector.

3. There is the need to consciously improve the infrastructural base of the nation, with keen interest paid on transport and communication sectors. This will go at length in creating a business-friendly atmosphere.

4. Moreover, structural mechanism and policy reforms are prerequisite for a vibrant, resilient and robust financial system that will strengthen the vertical linkage between the financial system and the manufacturing sector.

\section{References}

[1] Adebayo, S. I. \& Onyeiwu, C. (2018). The determinants of profitability of manufacturing firms in Nigeria. International Journal of Economics, Commerce and Management, 6(4), 479 - 493.

[2] Adeyemi, P.A. \& Olufemi, O.B. (2016). The Determinants of Capacity Utilization in the Nigerian Manufacturing Sector. Journal of Economics and Sustainable Development, 7(5), 20-31.

[3] Ajudua, 1E. I. \& Ojima, D. (2016). Modelling the Determinants of Output in the Nigerian Manufacturing Sector. International Journal of Innovative Finance and Economics Research 4(1),1-12.

[4] Akinyele, S. T., Akinyele, F. E. \& Ajagunna, O. D. (2016). Infrastructural Development As Predictor To Small \& Medium Enterprises Performance In Nigeria. Kuwait Chapter of Arabian Journal of Business and Management Review, 6(3), 40-53.

[5] Anigbogu, T. U., Edoko, T. D. \& Okoli, I. M. (2016). Foreign Direct Investment and Poverty Reduction in Nigeria. International Journal of Business and Management Invention, 5(6), 19-28.

[6] Debbie, A. (2004). "Small Firms are the Backbone of Nigerian Economy". Economic Analysis. www.mycbsearch.com

[7] Ebitu, E. T., Basil. G. \& Ufot, J. A. (2016). An appraisal of Nigeria's Micro, Small And Medium Enterprises (Msmes): Growth, Challenges And Prospects. International Journal of Small Business and Entrepreneurship Research, 4(4), 1-5.

[8] Hansen, G. S. \& Wernerfelt, B. (1989). Determinants of Firm Performance: The Relative Importance of Economic and Organizational Factors.Strategic Management Journal, 10(5), 399-411.
[9] Loto, M.A (2012). The Determinants of Output Expansion in the Nigerian Manufacturing Industries. Journal of Emerging Trends in Economics and Management Sciences, 3(6), 991-996.

[10] Mohammed, B. S. (2017). Impact of SMEs on Employment Generation in Nigeria. Journal of Humanities and Social Science, 22(9), 43-50.

[11] Mojekwu, J. N. \& Iwuji, I. I. (2012). Factors Affecting Capacity Utilization Decisions in Nigeria: A Time Series Analysis. International Business Research, 5(1), 157163.

[12] National Bureau of Statistics [NBS] (2014). Nigerian Gross Domestic Product Report: Quarter Four 2014

[13] National Bureau of Statistics [NBS] (2018). Nigerian Gross Domestic Product Report: Quarter Four 2018

[14] Obembe, Olufemi B, Adebisi S.A. \& Adesina J.A. (2011) Bank Loans, Ownership Structure and Efficiency of Listed Manufacturing Firms in Nigeria Advances in Management \& Applied Economics, (online) International Scientific Press, vol.1, no.2, 2011, 221-236 ISSN: 1792-7544 (print version), 1792-7552.

[15] Oburota, C. S. \& Ifere, E. O. (2017). Manufacturing Subsector and Economic Growth in Nigeria. British Journal of Economics, Management \& Trade, 17(3): 1-9.

[16] Okunade, S. O. (2018). Effect of Capacity Utilisation on Manufacturing Firms' Production in Nigeria. Global Journal of Management and Business Research: BEconomics and Commerce, 18(1), 29-38.

[17] Otalu, J. A \& Keji, S. A. (2015). An assessment of the determinants of industrial sector growth in Nigeria. Quest Journal of Research in Business and Management, 3(7), 01-09.

[18] Sangosanya, A.D. (2011). Firms Growth Dynamics in Nigeria's Manufacturing Industry: A Panel Analysis. Journal of Applied Econometric Review 1(1), 19-26.

[19] Simon-Oke, 0. 0. \& Awoyemi, O. V. (2010). Manufacturing Capacity Utilization and Industrial Development in Nigeria: An Assessment (1976 - 2005). African Research Review, 4(2), 265-275.

[20] Tybout, J.R. (2000), Manufacturing Firms in Developing Countries: How Well Do They Do and Why? Journal of Economic Literature, 38, 11-44.

[21] Ududechinyere, C., Eze, O. M. \& Nweke, A. M. (2018). An analysis of the effect of manufacturing sector on the growth of the Nigerian economy. IOSR Journal of Business and Management, 20(4), 34-46. 